\title{
Education Of Covid-19 Prevention And Providing Of Handsanitizer In Pressing The Spread Of Corona Virus Infection In Cempedak Lobang Village, Sei Rampah Sub-District, Serdang Bedagai District
}

\author{
${ }^{1 *}$ Effendy De Lux Putra, ${ }^{1}$ Sri Yuliasmi, ${ }^{1}$ Henny Sri Wahyuni and ${ }^{2}$ Bayu Eko Prasetyo \\ ${ }^{1}$ Department of Pharmaceutical Chemistry, Faculty of Pharmacy, Universitas Sumatera Utara, Medan, \\ Indonesia \\ ${ }^{2}$ Department of Pharmaceutical Technology, Faculty of Pharmacy, Universitas Sumatera Utara, Medan, \\ Indonesia \\ *Email: effendy@usu.ac.id
}

\begin{abstract}
Coronavirus disease (Covid-19) was declared a pandemic (a disease whose spread has spread throughout the world) by WHO on March 9, 2020. This disease can be transmitted to everyone regardless of age and has a very detrimental impact both in the health and economic fields. Cempedak Lobang Village is one of the villages in Serdang Bedagai Regency which was affected by the Covid-19 pandemic. One of the precautions that can be taken to reduce the spread of Covid-19 is the application of physical distancing and maintaining hand hygiene through the use of a hand sanitizer. However, the availability of hand sanitizers has become scarce and very expensive so that it is difficult for the public to reach. In addition, there is a lack of compliance and public awareness of the importance of implementing physical distancing, using masks and maintaining personal hygiene, so it is feared that the spread of the virus will become more widespread. This community service is beneficial in providing one solution and alternative to the community of this village in solving health problems that are currently endemic. The team will disseminate and educate on how to prevent Covid-19 infection. Hand sanitizers provided with formulas according to WHO standards and prepared by the community services team as well as educating on how to use and manufacture them so that they can stimulate the community to make their hand sanitizers.
\end{abstract}

Keywords: Covid-19, Cempedak Lobang, hand sanitizer

\begin{abstract}
Abstrak
Penyakit Coronavirus (Covid-19) dinyatakan sebagai pandemi (penyakit yang penyebarannya telah menyebar ke seluruh dunia) oleh WHO pada tanggal 9 Maret 2020. Penyakit ini dapat menular ke semua orang tanpa memandang usia dan berdampak sangat merugikan baik bagi kesehatan. dan bidang ekonomi. Desa Cempedak Lobang merupakan salah satu desa di Kabupaten Serdang Bedagai yang terdampak pandemi Covid-19. Salah satu langkah pencegahan yang dapat dilakukan untuk mengurangi penyebaran Covid-19 adalah dengan penerapan jarak fisik dan menjaga kebersihan tangan melalui penggunaan hand sanitizer. Namun, ketersediaan hand sanitizer menjadi langka dan sangat mahal sehingga sulit dijangkau masyarakat. Selain itu masih kurangnya kepatuhan dan kesadaran masyarakat akan pentingnya penerapan jarak fisik, penggunaan masker dan menjaga kebersihan diri, sehingga dikhawatirkan penyebaran virus akan semakin meluas. Pengabdian masyarakat ini bermanfaat dalam memberikan salah satu solusi dan alternatif kepada masyarakat desa ini dalam mengatasi
\end{abstract}


masalah kesehatan yang sedang mewabah. Tim akan melakukan sosialisasi dan edukasi tentang cara mencegah infeksi Covid-19. Hand sanitizer diberikan formula sesuai standar WHO dan disiapkan oleh tim pengabdian masyarakat serta mengedukasi cara penggunaan dan pembuatannya sehingga dapat merangsang masyarakat untuk membuat hand sanitizer sendiri.

Keywords: Covid-19, Cempedak Lobang, hand sanitizer

\section{INTRODUCTION}

Serdang Bedagai Regency is an area adjacent to Deli Serdang Regency and not too far from Medan City. Sei Rampah District consists of several villages, one of which is Cempedak Lobang Village. The residents of Cempedak Lobang Village have various livelihoods, and most of them are of a productive age with relatively high mobility. In Serdang Bedagai Regency, there have not been any positive Covid-19 patients found. However, there are more than five patients under surveillance (PDP), so the status of the area has become a red zone when viewed from the distribution of PDP.

\section{Partner issues}

Several vital issues faced by the community of Cempedak Lobang village, Serdang Bedagai Regency, North Sumatra, includes:

1. The residents of Cempedak Lobang Village are generally of productive age, with high mobility which can become Covid-19 carriers. With this educational activity, it can add insight and knowledge and increase awareness of the importance of physical distancing and maintaining personal hygiene, especially in preventing the spread of Covid-19.

2. Scarcity of hand sanitizers which resulted in a very significant increase in prices so that people could not afford it. The provision of hand sanitizers can help the community, especially in the village of Cempedak Lobang, to meet their needs for hand sanitizers.

3. The population of productive age, on average, work like homemakers, with this educational activity it can encourage/stimulate a sense of entrepreneurship for mothers

4. If it is analyzed from a financial perspective, homemakers do not have additional income. The training in making hand sanitizers purposes to improve the women of Cempedak Lobang Village knowledge, especially in produce hand sanitizers by themselves. They could improve their health, high economic value and increase the productivity of mothers and the family income

Based on the experience of the author who has come directly to the surrounding location, public awareness is still lacking about the dangers of Covid-19. They did not implement the full preventive measures for Covid-19, such as not implementing physical distancing and personal hygiene properly, and there is no provision of hand sanitizer and information on how to use it correctly and adequately. Education about the dangers and prevention of Covid-19 is very needed by society. As well as information on how to manufacture according to WHO recommendations and use the correct hand sanitizer. It will produce a healthier society, care for personal health and the environment, stimulate the entrepreneurial spirit of mothers to be able to produce their hand sanitizers which are safe and reduces the spread of Covid -19 . 


\section{METHODS}

Several members of the service team have approached and interviewed the women's association located in Cempedak Lobang Village, Sei Rampah District, Deli Serdang Regency and also to the Sei Rampah Sub-District Head and Village Head and residents. Their welcome was very enthusiastic by being willing provided counselling, guidance and training in Covid19 prevention education activities and provision of hand sanitizers in order to reduce the spread of coronavirus infection in Cempedak Lobang Village, Sei Rampah District, Serdang Bedagai Regency, North Sumatra.

Education on prevention and the impact of Covid-19 on the community was carried out using the Active Community Learning Method (CBMA) method. This method demands activeness from the community. In this case, the community (mothers) will be given an exciting booklet to read, which contains the dangers and ways of preventing the spread of the coronavirus. Banners will also be installed in several corners of the village to remind people of the dangers and importance of prevention. The service team chose this system to implement physical distancing in order to reduce the spread of the coronavirus. Later the participants will be evaluated through a form that will be sent to each participant and work with the village head of Cempedak Lobang to monitor changes in attitudes and behaviour of participants who have participated in this service activity. The community services team can evaluate the information has been delivered to the public about dangerous and prevention of the spread of the coronavirus.

The provision of hand sanitizers is carried out in several stages of the implementation of activities including:

(1) Preparation information about potential resources, orientation for the preparation of hand sanitizers to be applied,

(2) Socialization through distributing brochures/booklets on the importance of using hand sanitizers,

(3) Implementation making hand sanitizers using a formula recommended by WHO with a combination of essential oils and several plants that have antiseptic properties. For this stage, the service team will video how to make and use hand sanitizers that are good and correct. Then the video will be given to the participants so that they can be studied and applied with a combination of several other herbal plants.

\section{RESULT AND DISCUSSION}

Community service in the form of Covid-19 Prevention Education and Provision of Hand Sanitizers in the Context of Suppressing the Spread of Corona Virus Infection in Cempedak Lobang Village, Sei Rampah District, Serdang Bedagai Regency, North Sumatra has been carried out since June 2020. All activities are carried out according to schedule. All participants were delighted and enthusiastic about participating in the workshop from start to finish, as evidenced by the results of the percentage of the 45 participants' activity assessment questionnaire of $66.7 \%$ very satisfied and $33.3 \%$ satisfied. 
Effendy De Lux Putra, et al Education Of Covid-19 Prevention And Providing Of Handsanitizer In Pressing The Spread Of Corona Virus Infection In Cempedak Lobang Village, Sei Rampah SubDistrict, Serdang Bedagai District

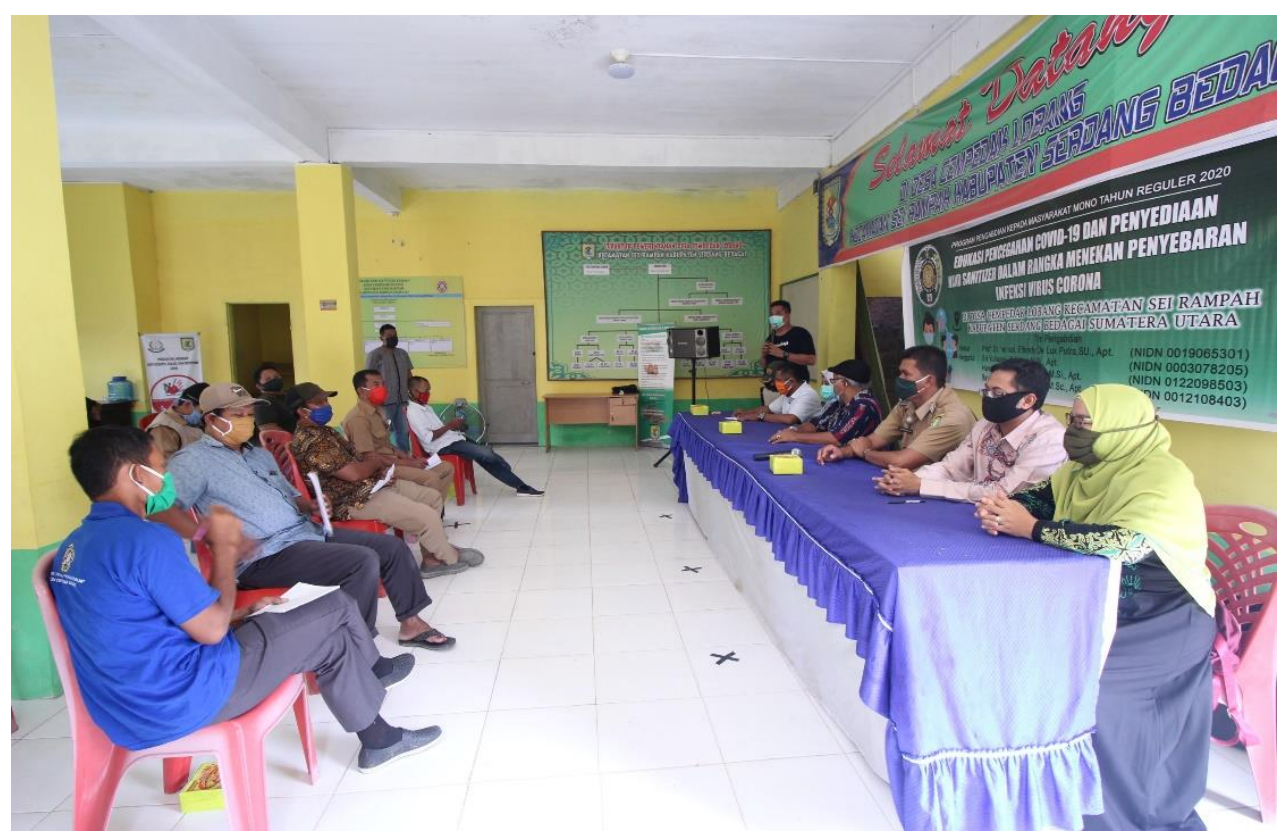

Figure 1. Socialization of community service activities in Cempedak Lobang Village

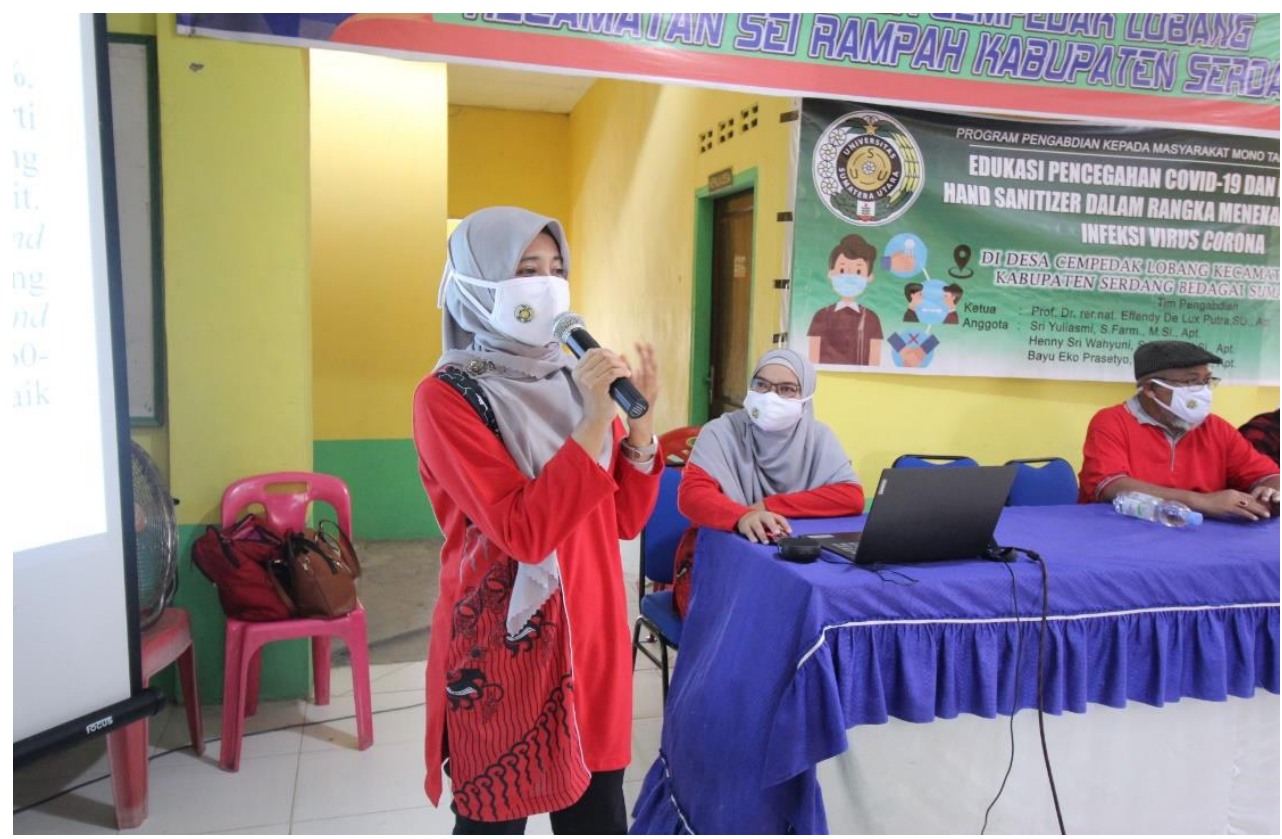

Figure 2. Speakers provide prevention education Covid-19 and manufacture of hand sanitizer 
Effendy De Lux Putra, et al Education Of Covid-19 Prevention And Providing Of Handsanitizer In Pressing The Spread Of Corona Virus Infection In Cempedak Lobang Village, Sei Rampah SubDistrict, Serdang Bedagai District

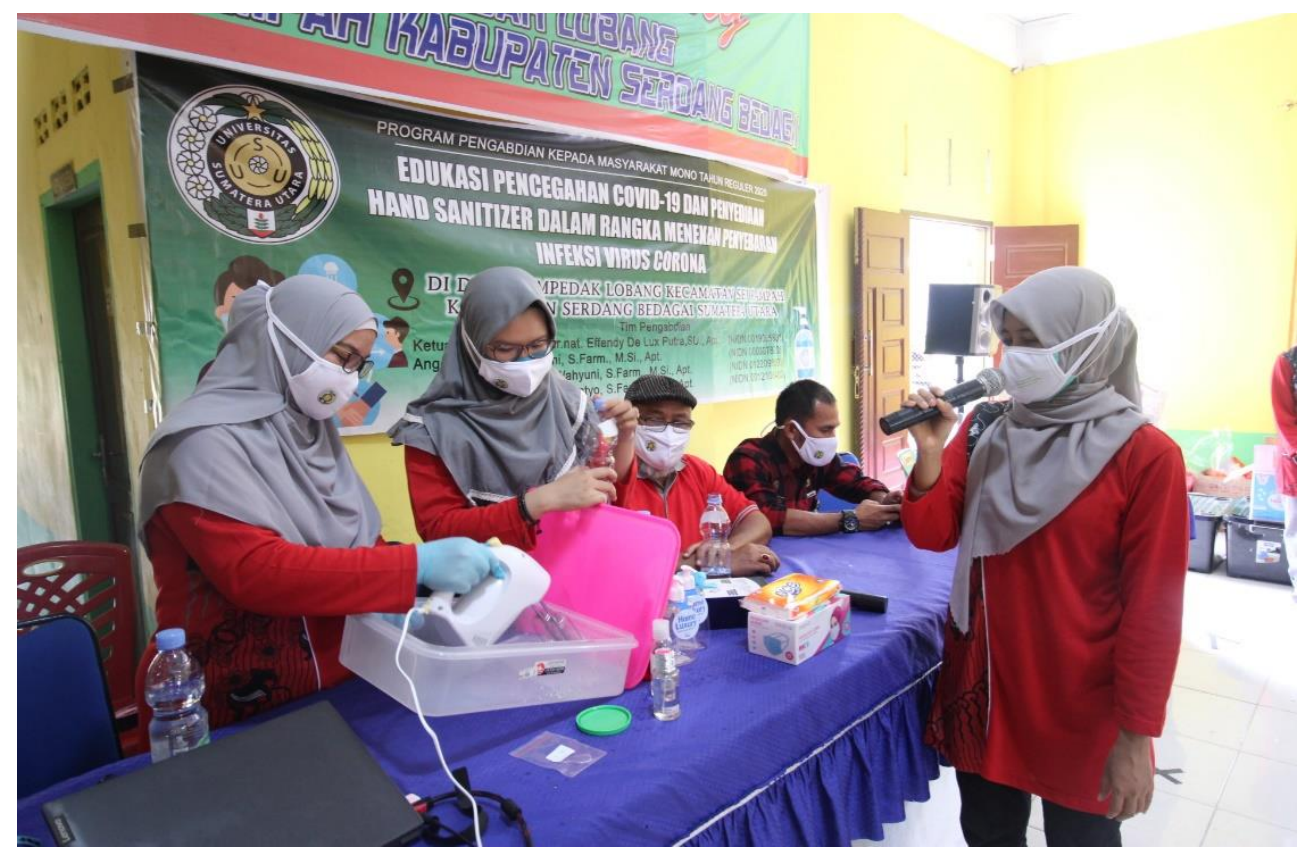

Figure 3. The practice of making hand sanitizers

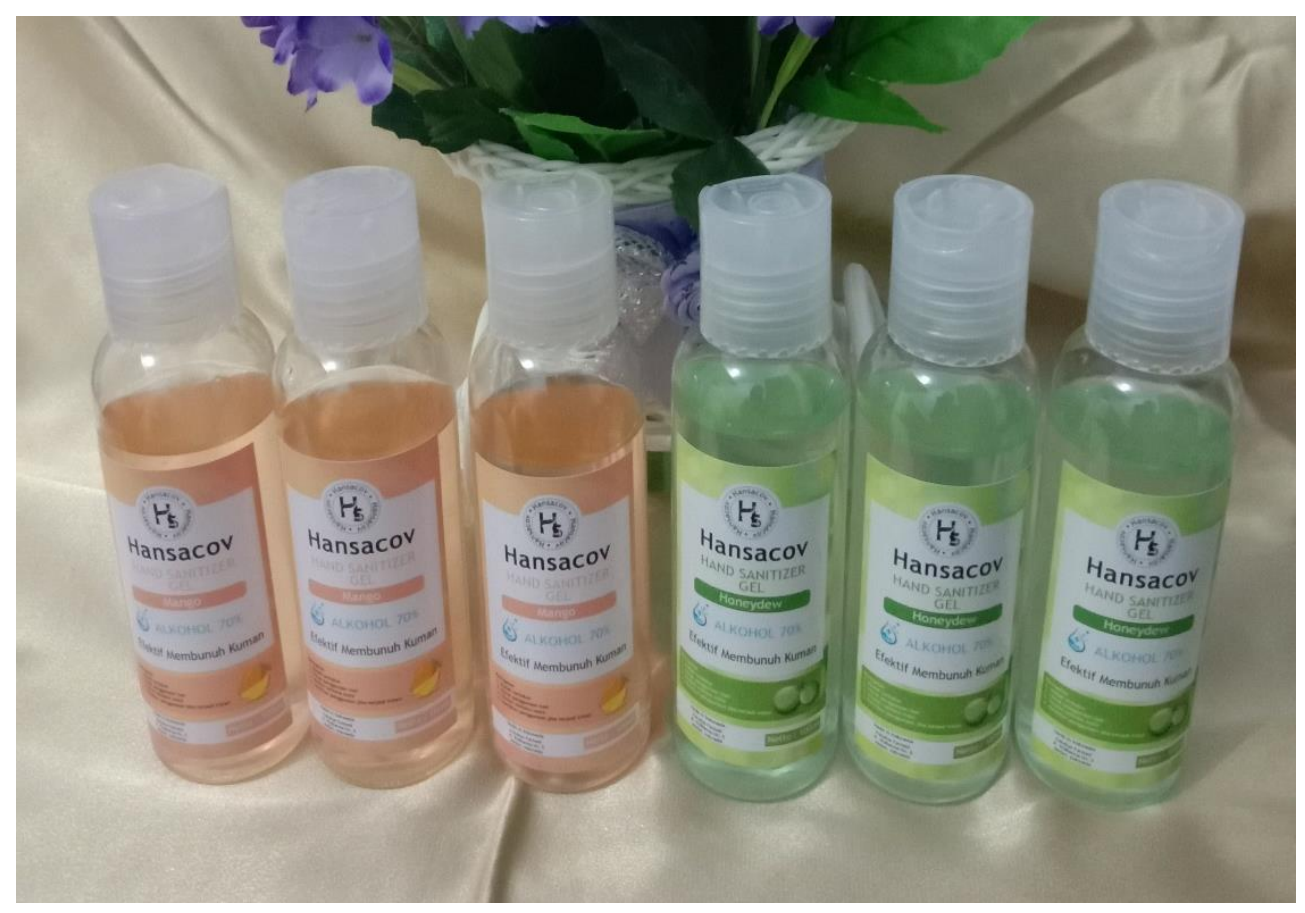

Picture 4. The finished hand sanitizer ready to be distributed to Cempedak Lobang Village community 
Effendy De Lux Putra, et al Education Of Covid-19 Prevention And Providing Of Handsanitizer In Pressing The Spread Of Corona Virus Infection In Cempedak Lobang Village, Sei Rampah SubDistrict, Serdang Bedagai District

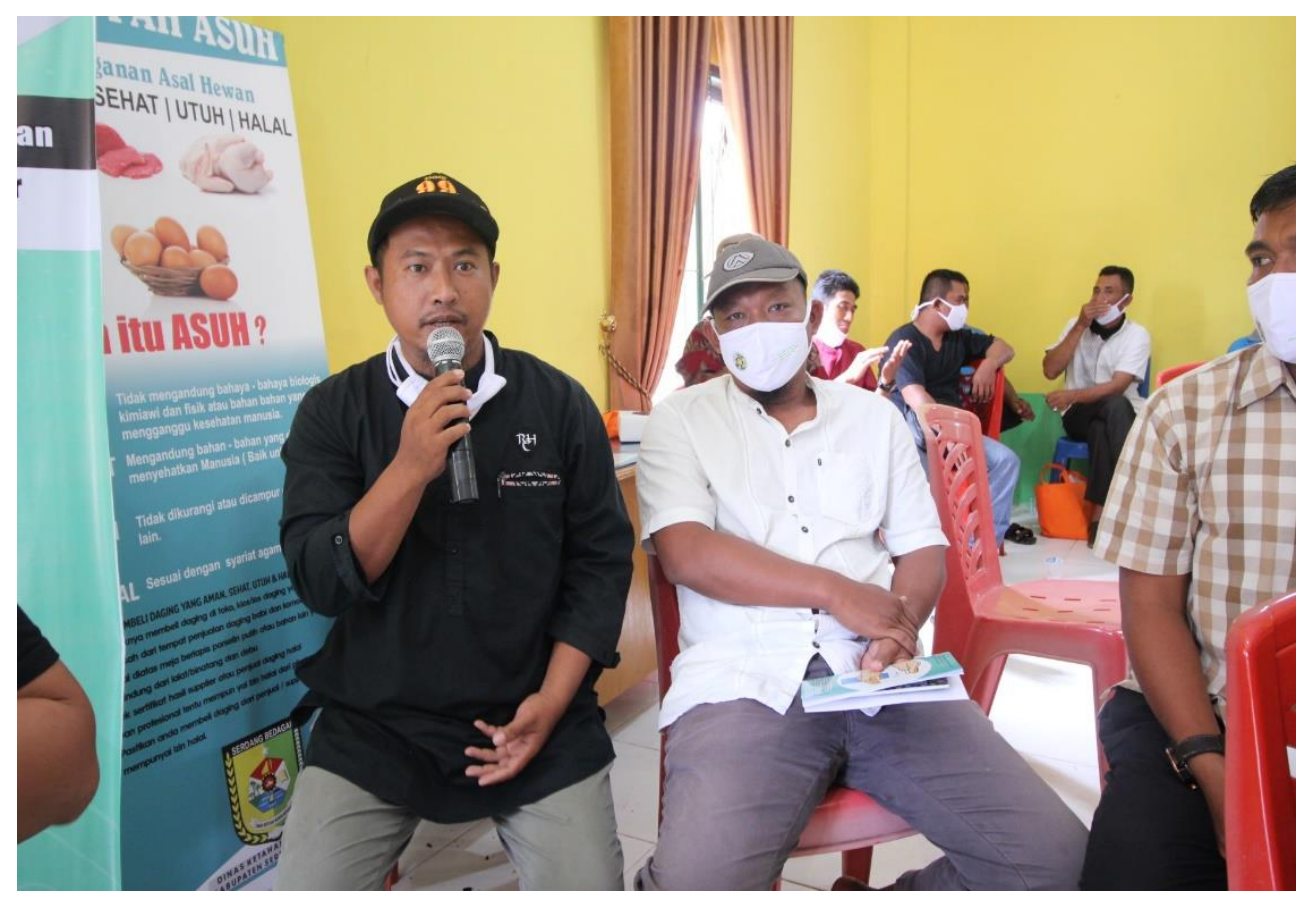

Figure 5. Questions and answers by participants regarding the theory and practice of making hand sanitizer

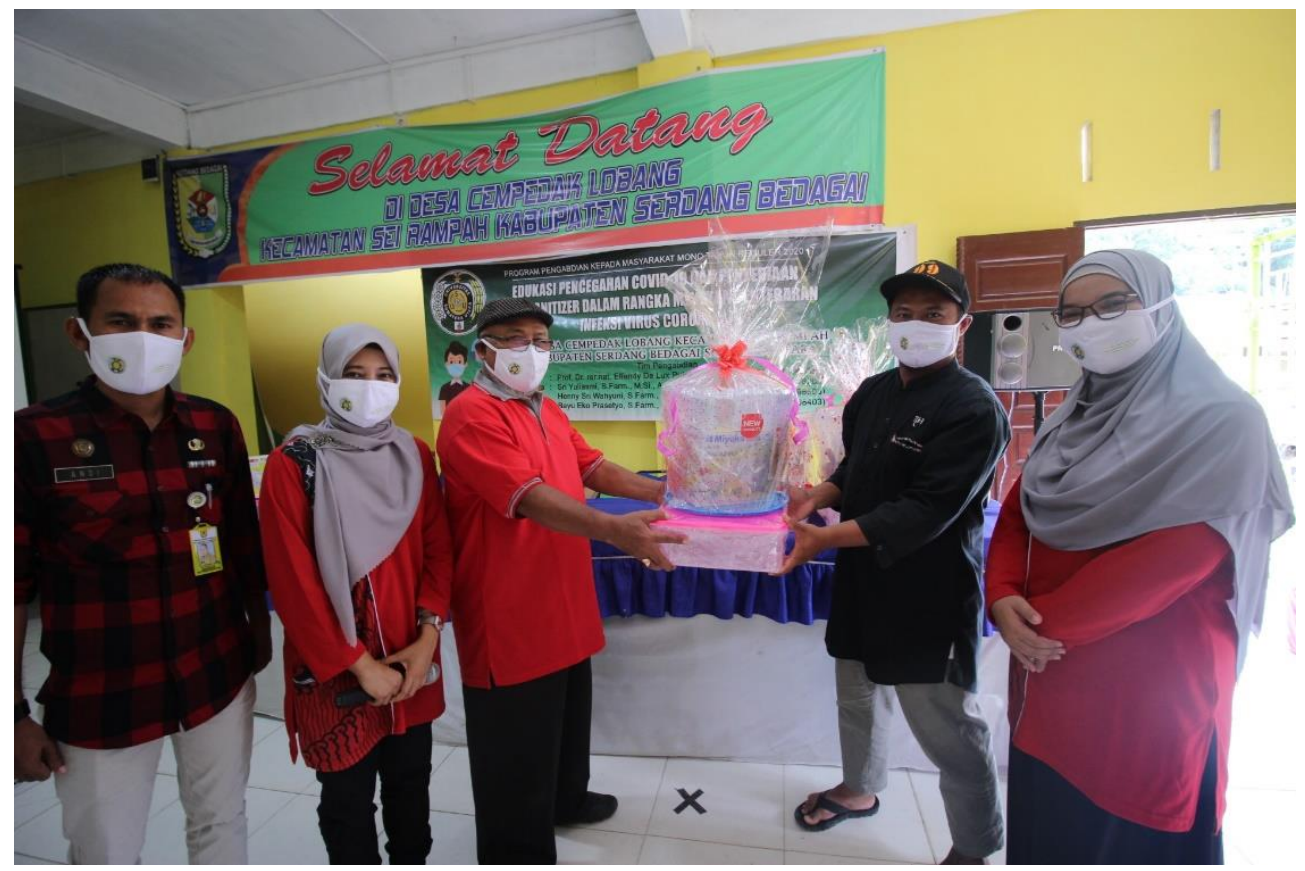

Figure 6. Delivery of tools needed by community service partners in the process of making hand sanitizers 


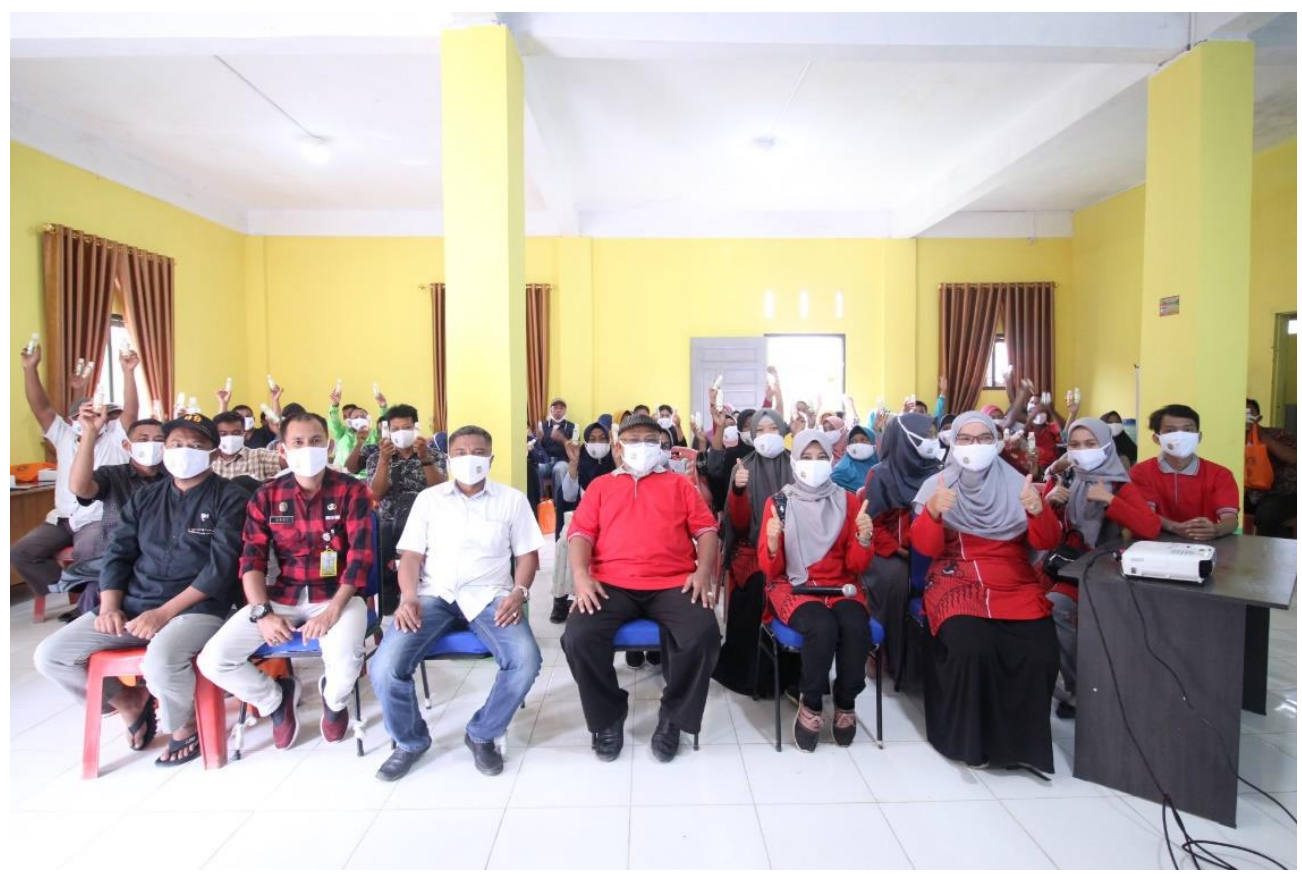

Figure 7. Photo with community service partners and participants community in Cempedak Lobang Village

All the hand sanitizers produced were given to the community in Cempedak Lobang Village. In addition, the equipment for making hand sanitizers provided is expected to be used by the community to continue the production of hand sanitizers to help the economy of the village society.

\section{CONCLUSSION AND SUGGESTION}

Covid-19 Prevention Education and Hand Sanitizer Provision in the Context of Suppressing the Spread of Corona Virus Infection in Cempedak Lobang Village, Sei Rampah District, Serdang Bedagai Regency, North Sumatra, has been carried out properly without significant obstacles. The active role of the resource persons who provide training, community service teamwork and very cooperative partner assistance much support the implementation of community service as expected. The hope is that the community service that has been carried out can provide positive benefits, especially for service partners in order to increase public awareness of the dangers and ways to prevent the spread of Covid-19 and spur the motivation of the village community to be able to provide their own hand sanitizers which can even be used as business opportunities, so that the economy and the health level of the community in Cempedak Lobang village are increasing. The community services have been carried out has reached the stage of implementing educational activities to prevent the spread of Covid-19 as well as training on how to make and use hand sanitizers. Therefore, we will continue until the final public service report is completed. 
Effendy De Lux Putra, et al Education Of Covid-19 Prevention And Providing Of Handsanitizer In Pressing The Spread Of Corona Virus Infection In Cempedak Lobang Village, Sei Rampah Sub-

District, Serdang Bedagai District

\section{ACKNOWLEDGMENT}

We would like to thank the Rector of USU for financial support by Regular mono year NonPNBP 2020 and all participants who have helped the implementation of this Community Service.

\section{REFERENCES}

Buana, D. R. (2020). Analisis Perilaku Masyarakat Indonesia dalam Menghadapi Pandemi Virus Corona (Covid-19) dan Kiat Menjaga Kesejahteraan Jiwa. SALAM: Jurnal Sosial dan Budaya Syar-i, 7(3).

Channel News Asia. (2020). Wuhan virus outbreak: 15 medical workers infected, 1 in critical condition. [Homepage on The Internet]. Cited January 28 2020. Available on: https://www.channelnewsasia.com/news/asia/wuhanpneumonia-outbreakhealth workers-coronavirus-12294212.

Dirjen. Pencegahan dan Pengendalian Penyakit-Kemenkes RI, 2020, Pedoman Pencegahan Dan Pengendalian COVID-19. Kementerian Kesehatan RI. Diterbitkan 27 Maret 2020.

Perhimpunan Dokter Paru Indonesia. (2020). Panduan Praktik Klinis: Pneumonia 2019- nCoV. PDPI: Jakarta.

Relman, E. (2020). Business insider Singapore. Cited January 28 2020. Available on: https://www.businessinsider.sg/deadly-china-wuhan-virusspreading-humanto-humanofficials-confirm-2020-1/?r=US\&IR=T.

Wang, Z., Qiang, W., Ke, H. (2020). A Handbook of 2019-nCoV Pneumonia Control and Prevention. Hubei Science and Technology Press. China

WHO. (2020). WHO Director-General's remarks at the media briefing on 2019-nCov on February 11 2020. Cited Feb 13rd 2020. Available on: https://www.who.int/dg/speeches/detail/who-director-generals-remarks-atthe-mediabriefing-on-2019-nCov-on-11-February-2020. (February 12 2020).

Yuliana, Y. (2020). Coronavirus diseases (Covid-19); Sebuah tinjauan literatur. Wellness And Healthy Magazine, 2(1), 187-192. 